\title{
Research of thermal performance properties of the wall construction products made of materials using heat power engineering waste
}

\author{
Dmitriy Kraynov ${ }^{1 *[0000-0003-3074-9090]}$, and Galina Medvedeva ${ }^{1 \text { [0000-0002-3507-606X] }}$ \\ ${ }^{1}$ Kazan State University of Architecture and Engineering, 420033 Kazan, Russia
}

\begin{abstract}
A technology for the utilization of technogenic waste from the oil and gas industrial complex (sulfur) and ash and slag waste from the combined heat and power plant for the manufacture of thermal insulation material with high strength and performance properties has been developed. A technological scheme is proposed. The optimal parameters and composition of the obtained thermal insulation materials have been determined. A numerical method for determining the thermal conductivity coefficient of a building product based on the calculation of a stationary temperature field is considered. The dependence of the thermal conductivity coefficient of a block on the value of the thermal conductivity coefficients of the base material and filler is obtained. The efficiency of block insulation has been determined. This method can be used at the design stage of wall products, varying their overall dimensions, the geometry of the slots and also using various thermal insulating materials as a void filler.
\end{abstract}

Keywords. Thermal conductivity coefficient, wall block, thermal insulation material, temperature field.

\section{Introduction}

The improvement and development of construction materials manufacturing and the increase in their economic productivity in the modern world will largely be formed by the expediency of using huge resources, attracting waste from various areas of the industrial field [1-2]. As a result of the uncontrolled effect of human society on the environment, environmental problems considered as large-scale ones are formed. Waste heat energy occupies one of the first places in volume, and in connection with the infinite improvement of technologies, the volume of industrial ash and slag waste (ASW) is increasing. According to this reason, it can be assumed that ash and slag dumps for the degree of unfavorable environmental impact will occupy one of the main places among industries. From year to year, at almost all combined heat and power plants (CHPP), the output of ash and slag exceeds one million ton, and at stations where ash fuel is burned, it can reach 5 million tons [3]. So, in the city of Kazan, in the Kirovsky ash dump, more than 600 thousand tons of ash slags have been accumulated, which occupies valuable land in the amount of 23 hectares [4]. It is known [5] that according to the study of the properties of the ash-slate mixture, in the grain composition, the mixture

\footnotetext{
*Corresponding author: dmitriy.kraynov@gmail.com
} 
can be attributed to the medium-grained mixture and the slag grain density and by bulk density - to the light concrete mixture.

Fuel porous slags can be used in the construction of monolithic wall structures, for the production of bricks, light concrete stones, in the preparation of lightweight thermal insulation concrete classes B2.5-B7.5, as well as thermal insulation materials [6-13]. In lightweight concrete, the fine aggregate can be replaced by ash. Taking into account the possibility of replacing already known wall materials by materials with ash and slag waste [14] in multilayer enclosing structures as a constructive material, it is possible to reduce the amount of capital costs for the construction of outdoor structures. The use of the ash and slag waste helps to save on materials - aggregates and fillers, and in addition when using ash and slag waste, it is possible to resolve the issue of waste disposal, which lie in the dumps, and at the same time damages the environment $[15,16]$. In the manufacture of concrete mixture, due to the substitution of the sandy ingredient, the number of pores may increase, which is accompanied by a decrease in the mass and density of the product, while the thermal insulation properties of the mixture increase [17]. However, composite materials modified by ash and slag waste have low strength and waterproof properties.

In order to stabilize the above properties of cement thermal insulation material we use the special technologies of impregnation in hydrophobic solutions and melts. Using these technologies, a hardening and hydrophobic layer is formed on the surface of the material. At the same time, the increase in strength is created by physical and chemical processes, the main of which are the following: pore filling, increase the density and in addition, the resistance to the destruction of the polymer component; healing of damage to the cement structure, preventing the spread of micro-cracks, and increasing the density of contacts between the components of the system by the adhesion and chemical interaction forces [18].

During the desulfurization of gas and oil approximately 12.5 million tons of sulfur waste is formed in Russia. Sulfur has a number of useful properties, such as strength, resistance to aggressive environments, water resistance, hydrophobicity [19]. Therefore, sulfur is recommended as an excellent material for the construction industry. Sulfur concrete is a composite material that may differ from the usual concrete in that it is impregnated with modified sulfur melt [20]. As fillers, construction sand and ash and slag waste from CHPP are used. When impregnating with a sulfur melt of concrete, such properties as durability and water resistance are largely increasing. The impregnated concrete has greater compressive strength than an unprofitable, the modulus of elasticity is doubled, the greatest chemical resistance to the effects of such aggressive environment, as solutions of acids and salts [21]. It can also be noted that when processing the material, the modified sulfur melt increases frost resistance, the water absorption of the material decreases and resistance to abrasion increases [22-24].

The use of the described production technologies of sulfur concrete can solve the environmental problem with the storage of waste industry, significantly reduce the cost of finished construction products and increase other technical and economic indicators of products. Therefore, the developed technologies that contribute to the utilization of excessive reserves of ash and slag waste of CHPP and sulfur oil and gas industry are relevant.

Blocks from various materials are actively used to build protective structures of buildings with efficient energy consumption: ceramics, lightweight and cellular concrete, etc. [25]. To improve the thermal protection properties of wall blocks, air cavities (crack) are created in them, and also fill them with thermal insulation materials. For experimental determination of the coefficient of thermal conductivity of building materials, the instrumental method is used $[26,27]$. This method is limited by the shape and sizes of test samples, which is not suitable for construction products, such as large-format wall blocks. During the test of the samples of the enclosing structures in the climatic chamber the thermal conductivity of the entire masonry is determined (not a single block). Full-scale tests suggest long-term measurements [28]. To eliminate the restrictions described under this study, it was tasked with the analysis 
of the heat-shielding properties of large-format multi-wall blocks made of various structural materials, including the sulfur concrete, obtained by disposal of oil and gas waste and the Ashland slag waste of CHPP. To solve the problem, the numerical method for determining the thermal conductivity coefficient of the wall block is used, based on the calculation of stationary temperature fields by the finite element method [29-30].

As an object of the study, a wall unit based on cement concrete is taken, in the development of which the waste of the oil and gas complex and heat efficiency is disposed of. During operation, experiments were carried out, as a result of which the optimal composition of concrete was chosen. Some measures are proposed to ensure the safety of the vital activity of the developed technology.

\section{Materials and methods}

\subsection{Production of samples and testing}

The following materials were used in the work:

- cement, strength class $42.5 \mathrm{~N}$;

- sulfur - waste of the Nizhnekamsky oil refinery. By chemical composition, this waste contains $99.9 \%$ of sulfur, i.e., practically represents a marketable product;

- construction sand;

- ash and slag waste of the CHPP-2 of the Kazan of the following composition (wt. \%):

$\mathrm{SiO}_{2}-47.7-52.2$

$\mathrm{Al}_{2} \mathrm{O}_{3}+\mathrm{TiO}_{2}-21.24-25.28$

$\mathrm{CaO}+\mathrm{MgO}-4.3$

$\mathrm{Fe}_{2} \mathrm{O}_{3}-5.2-5.9$

$\mathrm{R}_{2} \mathrm{O}-1.84-19.03$

$\mathrm{SO}_{3}-0.2$.

The studies used compositions that were prepared by mixing the initial components (cement: sand: ash and slag waste) in the specified ratios. After the resulting mixtures were filled in a form of $20 \times 20 \times 60 \mathrm{~mm}$, it was found that the optimal ratio in compositions cement: filler (sand and ash and slag waste) is 1:3. Next, the obtained compositions were dried in a drying cabinet for an hour at a temperature of $100^{\circ} \mathrm{C}$ and then soaked in a sulfur melt at a temperature of $140^{\circ} \mathrm{C}$.

Table 1. Comparative characteristics of the strength and operational properties of optimal samples of cement concrete containing ash and slag waste impregnated in sulfur melt and other lightweight concrete.

\begin{tabular}{|l|l|c|c|c|c|}
\hline \multicolumn{1}{|c|}{ Materials } & Sample composition, ratio & $\begin{array}{c}\text { Density, } \\
\mathrm{g} / \mathrm{cm}^{3}\end{array}$ & $\begin{array}{c}\text { Strength, } \\
\mathrm{MPa}\end{array}$ & $\begin{array}{c}\text { Water } \\
\text { absorption, } \\
\%\end{array}$ & $\begin{array}{c}\text { Thermal } \\
\text { conductivity, } \\
\mathrm{W} /\left(\mathrm{m} \cdot{ }^{\circ} \mathrm{C}\right)\end{array}$ \\
\hline $\begin{array}{l}\text { Heatinsulatingmaterial } \\
\text { based on ASW, optimal } \\
\text { composition }\end{array}$ & cement:sand:ASW =1:1:2 & 1.44 & 4.2 & 17 & 0.15 \\
\hline $\begin{array}{l}\text { Heatinsulatingmaterial, } \\
\text { based on sulfur }\end{array}$ & $\begin{array}{l}\text { cement:sand:ASW =1:1:2, } \\
\text { impregnated with sulfur melts }\end{array}$ & 1.178 & 35.7 & 2.8 & 0.128 \\
\hline Aerated concrete & $\begin{array}{l}\text { cement, lime, quartz sand, water } \\
\text { and special gauge additives }\end{array}$ & $0.6-1.0$ & $2.5-5$ & 20 & $0.14-0.29$ \\
\hline Foam concrete & $\begin{array}{l}\text { cement, sand, water, foaming } \\
\text { agent }\end{array}$ & $0.6-1.0$ & $1.5-2.0$ & 22 & $0.14-0.29$ \\
\hline
\end{tabular}


The obtained samples were studied using physical and mechanical tests. The results of the materials obtained are shown in Table 1. A comparison of the strength and operational properties of the optimal samples of cement concrete containing ash and slag waste impregnated in sulfur melt and other lightweight concrete was carried out.

From the table it can be seen that when comparing the strength and operational properties of samples without impregnation, as well as impregnated in sulfur melt, there is a significant improvement in physical and mechanical indicators in impregnated samples. The high strength and low water absorption can be explained by the structure. Due to the large content of ash and slag waste, large open pores were formed in the structure, which ensured the high degree of impregnation with the melt of sulfur. The sulfur formed a strong water-resistant structure with the material during hardening. The same explains the low thermal conductivity of the samples of this composition. So, sulfur concrete with a density of $1178 \mathrm{~kg} / \mathrm{m}^{3}$ has a thermal conductivity of $0.128 \mathrm{~W} /\left(\mathrm{m} \cdot{ }^{\circ} \mathrm{C}\right)$. For comparison, the thermal conductivity of foam concrete with a density of $1000 \mathrm{~kg} / \mathrm{m}^{3}$ is $0.29 \mathrm{~W} /\left(\mathrm{m}^{\circ}{ }^{\circ} \mathrm{C}\right)$, and of aerated concrete $-0.31 \mathrm{~W} /\left(\mathrm{m}^{\circ}{ }^{\circ} \mathrm{C}\right)$.

\subsection{Determination of the coefficient of thermal conductivity of the construction product}

As a construction product, a wall block is considered, which has the following dimensions: length $390 \mathrm{~mm}$, thickness $190 \mathrm{~mm}$, height $190 \mathrm{~mm}$. The block can be made of various materials characterized by different density and thermal conductivity. For the analysis, the range of values for the thermal conductivity of the block material is selected from 0.1 to 2 $\mathrm{W} /\left(\mathrm{m} \cdot{ }^{\circ} \mathrm{C}\right)$. To increase the efficiency of the thermal protection properties of the wall block, rectangular through holes in height (cavity) are performed. The amount and size of the cavities varies: four $45 \mathrm{~mm}$ thick or eight with the thickness of $20 \mathrm{~mm}$ (Fig. 1).

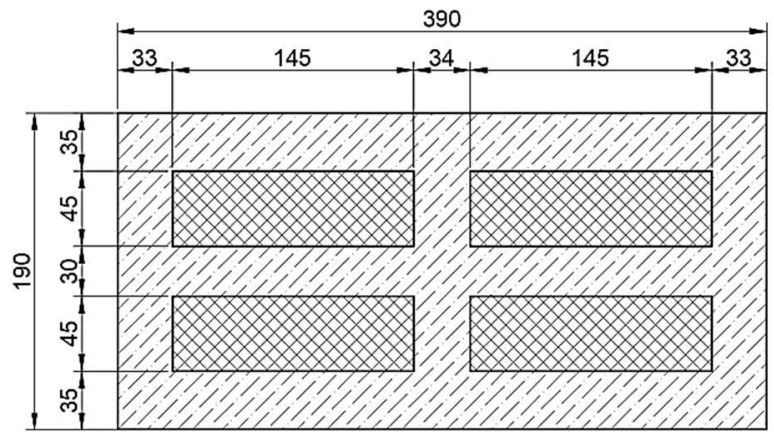

a

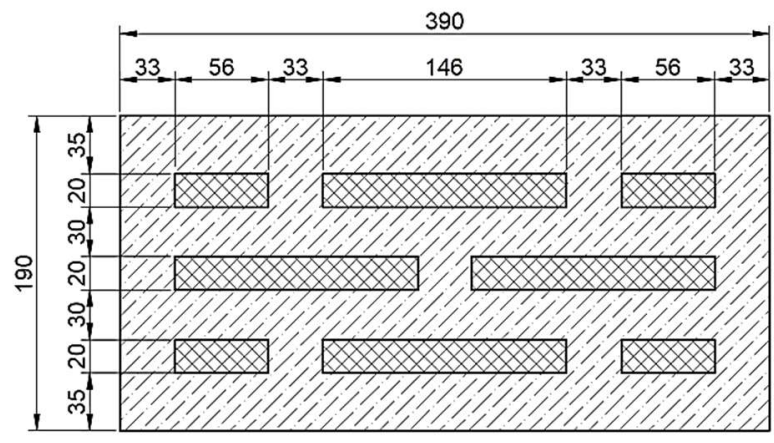

b

Fig. 1. Geometric characteristics of wall blocks: $a$ - four cavities block; $b$ - eight cavities block). 
To reduce the thermal conductivity of the wall, block the cavity block is filled with a lower thermal conductivity material, $\lambda_{\text {cavity }}$, from the range from 0.03 to $0.4 \mathrm{~W} /\left(\mathrm{m}^{\circ}{ }^{\circ} \mathrm{C}\right)$ or remain empty. In the second case closed air layers are formed in the cavities, an effective thermal conductivity coefficient which is determined by the formula:

$$
\lambda_{\text {airgap }}=\frac{d_{\text {airgap }}}{R_{\text {airgap }}}
$$

$d_{\text {air gap }}$ - thickness of the closed air layer in the direction perpendicular to the heat flow, $\mathrm{m}$;

$R_{\text {air gap }}$ - thermal resistance of the closed air layer, $\left(\mathrm{m}^{2 .}{ }^{\circ} \mathrm{C}\right) / \mathrm{W}$.

The values of the effective coefficient of thermal conductivity of closed air suits in the cavities with positive and negative temperatures defined by formula (1) are presented in Table 2 .

Table 2. Thermal characteristics of vertical closed air layers at different air temperatures in the layer.

\begin{tabular}{|c|c|c|c|c|}
\hline \multirow{2}{*}{$\begin{array}{c}\text { Thickness, } \\
\mathrm{mm}\end{array}$} & \multicolumn{2}{|c|}{ Positive } & \multicolumn{2}{c|}{ Negative } \\
\cline { 2 - 5 } & $R_{\text {air gap }},\left(\mathrm{m}^{\left.2 \cdot{ }^{\circ} \mathrm{C}\right) / \mathrm{W}}\right.$ & $\lambda_{\text {air gap }}, \mathrm{W} /\left(\mathrm{m}^{\circ}{ }^{\circ} \mathrm{C}\right)$ & $R_{\text {air gap }},\left(\mathrm{m}^{2} \cdot{ }^{\circ} \mathrm{C}\right) / \mathrm{W}$ & $\lambda_{\text {air gap }}, \mathrm{W} /\left(\mathrm{m}^{\circ}{ }^{\circ} \mathrm{C}\right)$ \\
\hline 45 & 0.14 & 0.321 & 0.168 & 0.269 \\
\hline 20 & 0.14 & 0.143 & 0.15 & 0.133 \\
\hline
\end{tabular}

In the process of creating masonry walls mortar can fall in air cavities. In this paper, the partial filling of air cavities with masonry mortar is not taken into account.

For the selected geometric configurations of the wall block with the cavities and thermal conductivity of the main material and the cavity filler, the stationary thermal conductivity is calculated by the finite element method.The boundary convection conditions are accepted: on the internal surface $t_{\text {int }}=20{ }^{\circ} \mathrm{C}, \alpha_{\text {int }}=8.7 \mathrm{~W} /\left(\mathrm{m}^{2} \cdot{ }^{\circ} \mathrm{C}\right)$, on the external surface $t_{\text {ext }}=-30$ ${ }^{\circ} \mathrm{C}, \alpha_{\text {ext }}=23 \mathrm{~W} /\left(\mathrm{m}^{2} \cdot{ }^{\circ} \mathrm{C}\right)$.

According to the results of modeling of stationary temperature fields heat losses through the computational domain are determined and the thermal conductivity coefficient of the wall block is calculated by the formula:

$$
\lambda_{\text {block }}=\frac{Q \cdot d}{\left(t_{i s}-t_{e s}\right) \cdot A}
$$

$Q$ - heat loss through the computational domain, $\mathrm{W}$;

$d$ - wall thickness, $\mathrm{m}$;

$t_{i s}, t_{e s}$ - temperature, respectively, on the internal and external surfaces of the wall block, ${ }^{\circ} \mathrm{C}$; $A$ - surface area of the wall block perpendicular to the heat flow, $A=0.0741 \mathrm{~m}^{2}$.

On the basis of calculated data, the efficiency coefficient of cavities and their fill in the formula is determined by:

$$
\eta=\frac{\lambda_{\text {material }}-\lambda_{\text {block }}}{\lambda_{\text {material }}}=1-\frac{\lambda_{\text {block }}}{\lambda_{\text {material }}},
$$

We write the formula to determine the thermal conductivity coefficient of the wall block using the efficiency coefficient of cavities:

$$
\lambda_{\text {block }}=\lambda_{\text {material }} \cdot(1-\eta)
$$

You can also determine the coefficient of the heterogeneity of the wall multiple blocks by the formula:

$$
r=\frac{\lambda_{\text {block }}}{\lambda_{\text {material }}}
$$

\section{Results}

The results of numerical modeling and calculations according to formulas (2)-(3) in the form of an example of the temperature field of the wall block with $\lambda_{\text {material }}=0.6 \mathrm{~W} /\left(\mathrm{m} \cdot{ }^{\circ} \mathrm{C}\right)$ and 
$\lambda_{\text {cavity }}=0.1 \mathrm{~W} /\left(\mathrm{m} \cdot{ }^{\circ} \mathrm{C}\right)$, as well as thermal conductivity dependences of the block and coefficient of the efficiency of cavities from the thermal conductivity of the base material of the block and the filler are presented in Fig. 2-4.

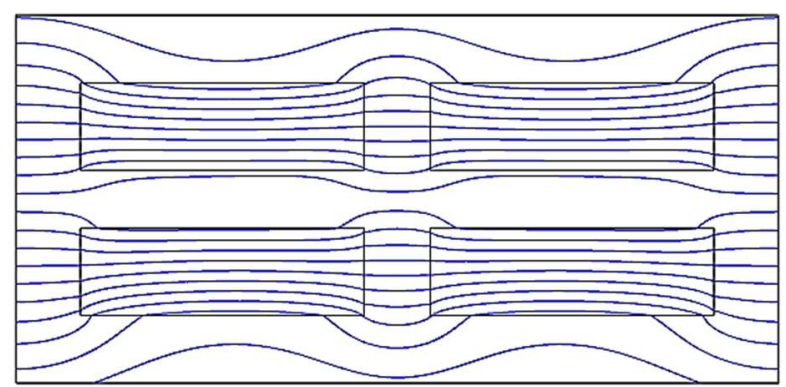

a) $Q=4.67 \mathrm{~W}$

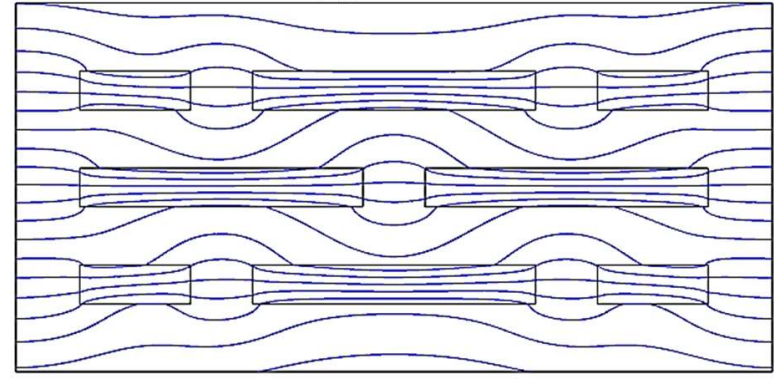

b) $Q=5.32 \mathrm{~W}$

Fig. 2. Temperature field of the wall block with $\lambda_{\text {material }}=0.6 \mathrm{~W} /\left(\mathrm{m} \cdot{ }^{\circ} \mathrm{C}\right), \lambda_{\text {cavity }}=0.1 \mathrm{~W} /\left(\mathrm{m} \cdot{ }^{\circ} \mathrm{C}\right)$. Isotherms pass with a step of 2 degrees: a) four cavities block; b) eight cavities block.
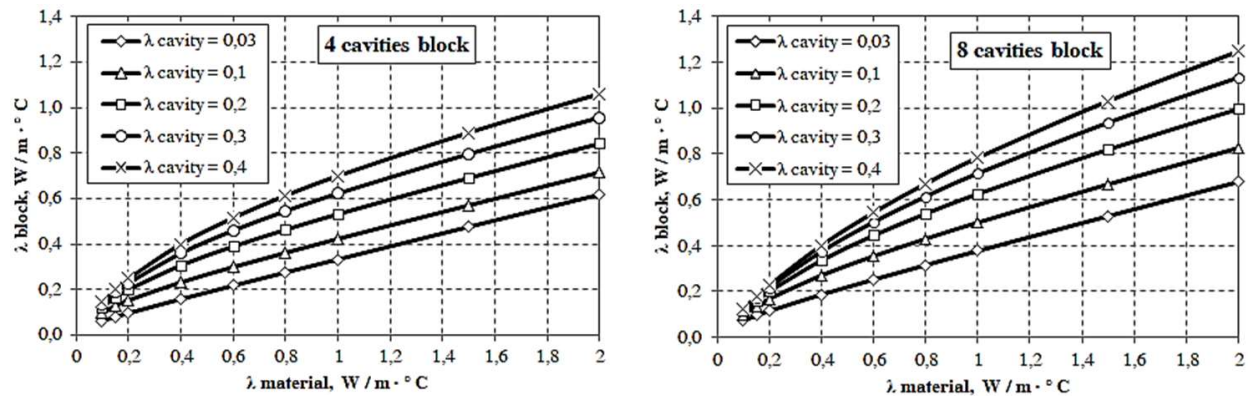

Fig. 3. Thermal conductivity of the wall block.
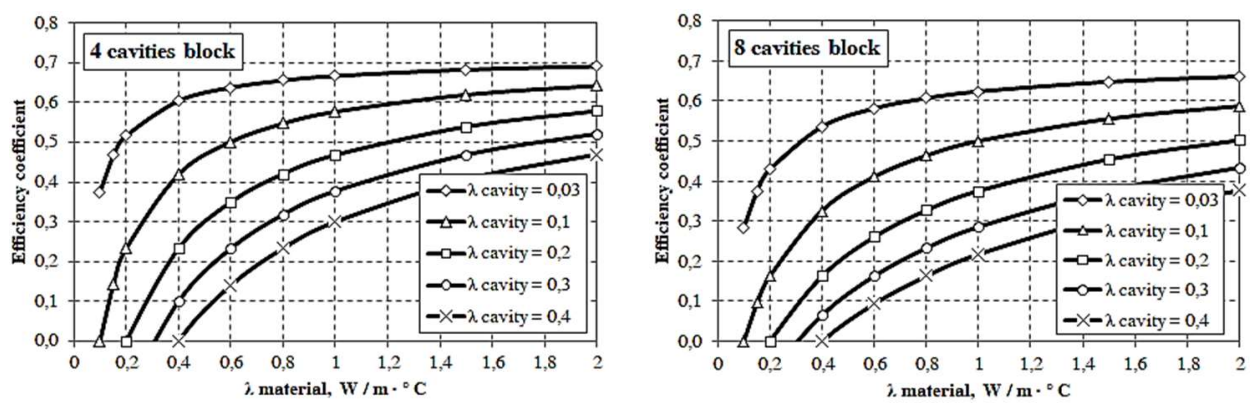

Fig. 4. Efficiency coefficient of the cavities using and their filling. 
The analysis of the results shows that for the variants of the wall block under consideration, the dependence of the $\lambda_{\text {block }}$ from $\lambda_{\text {material }}$ is a linear correlation function when $\lambda_{\text {cavity }}<0.1 \mathrm{~W} /\left(\mathrm{m}^{\circ}{ }^{\circ} \mathrm{C}\right)$. The dependence of $\lambda_{\text {block }}$ on $\lambda_{\text {material }}$ is described by a polynomial of the third degree when $\lambda_{\text {cavity }}>0.1 \mathrm{~W} /\left(\mathrm{m}^{\circ}{ }^{\circ} \mathrm{C}\right)$.

Figures 3-4 show that there is a noticeable improvement in thermal protection properties of the blocks of the considered configuration, when the cavities are used. The maximum efficiency coefficient does not exceed 0.7 . Using less thermally conductive materials to fill the cavities does not always lead to a significant decrease in the thermal conductivity of the

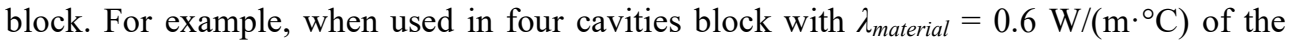
aggregate with twice smaller thermal conductivity $\left(\lambda_{\text {cavity }}=0.3 \mathrm{~W} /\left(\mathrm{m}^{\circ}{ }^{\circ} \mathrm{C}\right)\right)$ the thermal conductivity of the block decreases by only $23 \%(\eta=0.23)$.

\section{Discussion}

For comparison we consider both wall blocks with different thermal conductivity of the main material: $\lambda_{\text {material }}=0.2$ and $0.8 \mathrm{~W} /\left(\mathrm{m} \cdot{ }^{\circ} \mathrm{C}\right)($ Fig. $5-6)$.
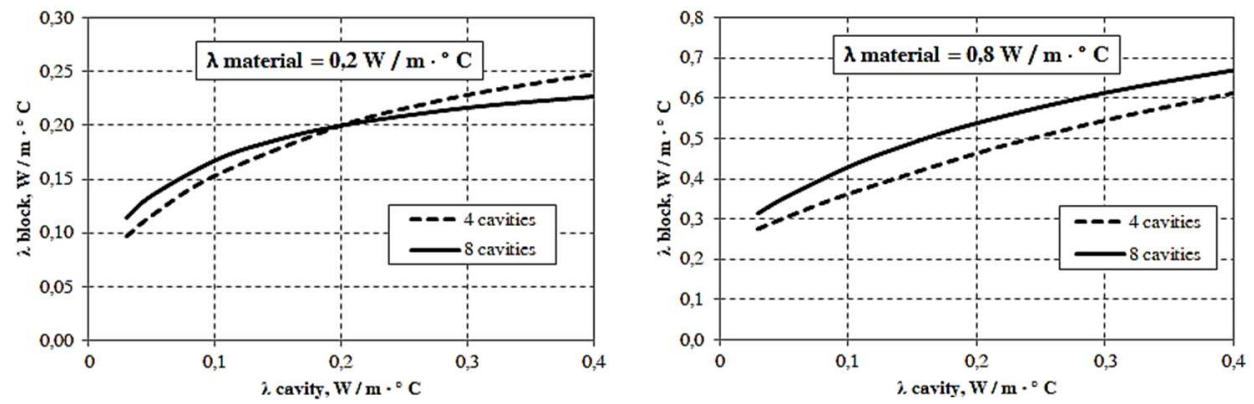

Fig. 5. Thermal conductivity of the wall block for $\lambda_{\text {material }}=0.2\left(\mathrm{~W} / \mathrm{m} \cdot{ }^{\circ} \mathrm{C}\right)$ and $\lambda_{\text {material }}=0.8 \mathrm{~W} /\left(\mathrm{m} \cdot{ }^{\circ} \mathrm{C}\right)$.
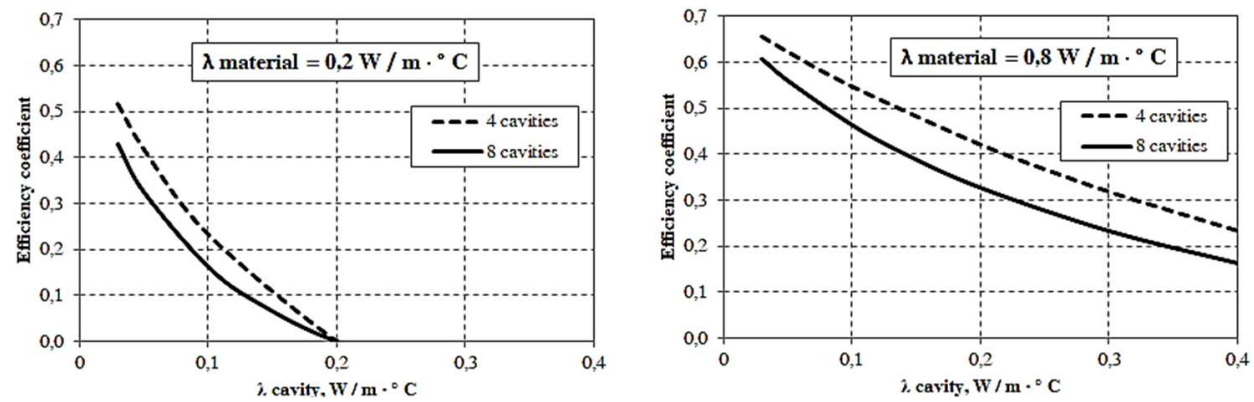

Fig. 6. Efficiency coefficient of the cavities using and their filling for $\lambda_{\text {material }}=0.2\left(\mathrm{~W} / \mathrm{m} \cdot{ }^{\circ} \mathrm{C}\right)$ and $\lambda_{\text {material }}$ $=0.8 \mathrm{~W} /\left(\mathrm{m} \cdot{ }^{\circ} \mathrm{C}\right)$.

When comparing the two blocks under consideration, it can be concluded that under the same operating conditions, the thermal conductivity of the four-slot block is lower than the eight-slot one, which is a positive point when choosing a construction product.

Studies have shown that with $\lambda_{\text {material }}=0.2 \mathrm{~W} /\left(\mathrm{m} \cdot{ }^{\circ} \mathrm{C}\right)$, the thermal conductivity of the unit with four slots is obtained more efficiently with thermal conductivity of cavities less than 0.2 $\mathrm{W} /\left(\mathrm{m}^{\circ}{ }^{\circ} \mathrm{C}\right)$. With a further increase in the thermal conductivity of cavities at $\lambda_{\text {material }}=$ $0.2 \mathrm{~W} /\left(\mathrm{m} \cdot{ }^{\circ} \mathrm{C}\right)$, the efficiency coefficient becomes negative. 
At $\lambda_{\text {material }}=0.8 \mathrm{~W} /\left(\mathrm{m} \cdot{ }^{\circ} \mathrm{C}\right)$, the configuration of a block with four cavities is $9-18 \%$ more efficient than of an eight cavities block. This is due to the number, size of the cavities and their location inside the block.

The issues obtained (Fig. 3, 7) are supposed to be used in the design and production of blocks with a given thermal conductivity. The algorithm of action is as follows: the geometric configuration of the block is selected, then on the specified thermal conductivity of the main material and the block, the required aggregate is selected. For example, it is required to obtain the thermal conductivity of the four cavities block equal to $\lambda_{\text {block }}=0.3 \mathrm{~W} /\left(\mathrm{m} \cdot{ }^{\circ} \mathrm{C}\right)$, if the thermal conductivity of the base material is $\lambda_{\text {material }}=0.6 \mathrm{~W} /\left(\mathrm{m} \cdot{ }^{\circ} \mathrm{C}\right)$. According to Fig. $3 \mathrm{a}$, it is necessary to select the aggregate with the thermal conductivity $\lambda_{\text {cavity }}=0.1 \mathrm{~W} /\left(\mathrm{m} \cdot{ }^{\circ} \mathrm{C}\right)$. For the eight-cavities block, with the same source data, the aggregate is required with thermal conductivity $\lambda_{\text {cavity }}=0.06 \mathrm{~W} /\left(\mathrm{m} \cdot{ }^{\circ} \mathrm{C}\right)$.
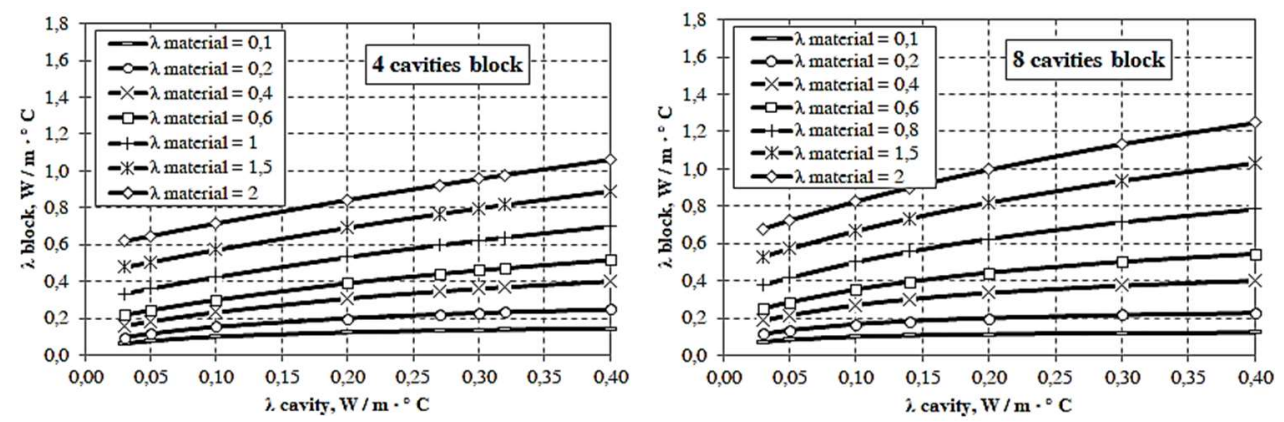

Fig. 7. The dependence of $\lambda_{\text {block }}$ from $\lambda_{\text {cavity }}$ and $\lambda_{\text {material }}$.

Also, if the task is to reduce the thermal conductivity of the wall block by a certain value, then using Fig. 4 it is possible to select the necessary cavity filler at a given thermal conductivity of the base material. For example, to reduce the thermal conductivity of the block made of material with $\lambda_{\text {material }}=0.152 \mathrm{~W} /\left(\mathrm{m}^{\circ}{ }^{\circ} \mathrm{C}\right)$, by $30 \%(\eta=0.3)$ it will be necessary to make four cavities and fill them with material with $\lambda_{\text {cavity }}=0.05 \mathrm{~W} /\left(\mathrm{m}^{\circ}{ }^{\circ} \mathrm{C}\right)$.

\section{Conclusion}

Thus, the possibility of using sulfur waste from the oil and gas complex in impregnating technologies in the production of building materials is investigated and proved. Based on the calculations, it can be assumed that the proposed material, sulfur concrete, has only the best indicators of the thermal conductivity coefficient, in contrast to the existing analogues. In addition, this material has another obvious advantage - low cost, because it uses waste from the heat and power industry and the oil and gas complex. The designed materials can be used in external wall structures.

To analyze the possible use of this material in the manufacture of large-format multicavity blocks, the calculated method for determining the thermal conductivity coefficient is considered. This approach makes it possible to obtain the necessary thermal protection characteristics at the stage of block development by changing the overall dimensions, shape and location of the internal cracks, taking into account their possible filling with various thermal insulation materials. 


\section{References}

1. V.D. Sultimova. Prospects for the disposal of ash and slag waste of thermal power plants, Materials of the National Conference, 10-14 (2019).

2. I.Y. Soktoev, E.A. Oksahaeva, D.R. Damdinova. Prospects for the use of gold waste heat power engineering in the production of building heat insulating materials, Bulletin of the Buryat State University. Chemistry. Physics 4, 36-40 (2018).

3. I.Yu. Danilovich, N.A. Scanavi. The use of fuel slags and ash for the production of building materials, (1988).

4. E.R. Barieva, E.A. Korolev, N.Kh. Galimullina, M.A. Fischenko. Assessment of the ecological hazard of ashlash waste of Kazan CHPP-2, Energy problems 5-6, 108-111 (2018).

5. U.A. Gaziev, H.A. Akramov. Waste industry in the production of building materials and products (2003).

6. M. Juengeret al. Supplementary cementitious materials for concrete: Characterization needs, Materials Research Society Symposium Proceedings 1488, 106-120 (2012). DOI: 10.1557/opl.2012.1536.

7. S. Abbas, M.A. Saleem, S.M.S. Kazmi, M. J. Munir. Production of sustainable clay bricks using waste fly ash: Mechanical and durability properties, Journal of Building Engineering 14, 7-14 (2017). DOI: 10.1016/j.jobe.2017.09.008.

8. E.V. Dunaevskaya. Application of heat waste waste for the manufacture of small-piece wall blocks, Young people and science: Collection of materials VI All-Russian Scientific and Technical Conference of Students, graduate students and young scientists, (2011).

9. L. Zhang. Production of bricks from waste materials - A review, Construction and Building Materials 47, 643-655 (2013). DOI: 10.1016/j.conbuildmat.2013.05.043.

10. M. Achik, H. Benmoussa, A. Oulmekki et al. Evaluation of technological properties of fired clay bricks containing pyrrhotite ash, Construction and Building Materials 269, 121312 (2021). DOI: 10.1016/j.conbuildmat.2020.121312.

11. A.A. Shakir, M.H. Wan Ibrahim, N.H. Othman, A. Ahmed Mohammed, M.K. Burhanudin. Production of eco-friendly hybrid blocks, Construction and Building Materials 257, 119536 (2020). DOI: 10.1016/j.conbuildmat.2020.119536.

12. I.Yu. Soktoeva, E.A. Oksahaeva, D.R. Damdinova. Features of the technological process of obtaining foam glass based on gastrointestinal materials and glass, Bulletin of the Buryat State University. Chemistry. Physics 4, 41-45 (2018). DOI: 10.18101/2306-23632018-4-36-40.

13. N.K. Manakova. Foams based on industrial waste, The Eurasian Scientific Journal 12 (4), (2020). DOI: 10.15862/21savn420.

14. G.A. Medvedeva, A.F. Lifanteva, A.A. Yusupova, R.R. Kashapov. Residues from fuel and power industries and glass industry as a basis of building materials, IOP Conference Series: Materials Science and Engineering 890, 012095 (2020). DOI: 10.1088/1757899X/890/1/012095.

15. R. Siddique. Waste materials and by-products in concrete, (2008).

16. R.S. Blissett, N.A. Rowson. A review of the multi-component utilisation of coal fly ash, Fuel 97, 1-23 (2012). DOI: 10.1016/j.fuel.2012.03.024.

17. D. Zoric, D. Lazar, O. Rudic, M. Radeka, J. Ranogajec, H. Hirsenberger. Thermal conductivity of lightweight aggregate based on coal fly ash, Journal of Thermal Analysis and Calorimetry 110 (1), 489-495 (2012). DOI: 10.1007/s10973-012-2339-x.

18. K.B. Ren, D.A. Kagi. Upgrading the durability of mud bricks by impregnation, Building and Environment 30 (3), 433-440 (1995). DOI: 10.1016/0360-1323(94)00056-X.

19. A.N. Volgusushev, N.F. Secerterkin. Production and application of sulfur concrete, (1991). 
20. G.A. Medvedeva, R.T. Akhmetova, V.F. Stroganov, L.R. Dirgamova. Technology of utilization of technogenicashlak and sulfuric waste in the manufacture of silicate concrete concrete, News of the Kazan State University of Architecture and Engineering 3 (29), 167-171 (2014).

21. E.V. Korolev, A.P. Proshin, V.T. Khrulev. Sulfur-based construction materials, (2003).

22. G.A. Medvedeva, R.T. Akhmetova, A.G. Labutkin. Use of wastes from thermal power industry in manufacturing of high-strength sulfur concrete, Research Journal of Pharmaceutical, Biological and Chemical Sciences 7, 1969-1981 (2016).

23. A.A. Yusupova, G.A. Medvedeva, A.A. Bobryshev. Technology and properties of composite materials with modifier of chloride aluminum, Materials Science Forum 946, 97-102 (2019). DOI: 10.4028/www.scientific.net/msf.946.97.

24. L.N. Shafigullin, A.A. Yusupova, G.A. Medvedeva. Influence of aluminum coating technology on industrial waste management, Helix 9 (5), $5442-5447$ (2019). DOI: 10.29042/2019-5442-5447.

25. G.I. Greenfeld, E.V. Korkina, P.P. Pustushkov, N.V. Pavlenko, I.V. Erofeeva. System protecting designs, provides increased energy savings in buildings, Scientific Herald of the Voronezh State University of Architecture and Civil Engineering. Construction and Architecture 3 (43), 25-35 (2016).

26. O.B. Barysheva, Y.K. Khabibullin. Investigation of the basic characteristics of the autoclaved gas industry, Izvestija KGASU 1 (35), 118-122 (2016).

27. M. Attalla. Experimental investigation of heat transfer and pressure drop of $\mathrm{SiO}_{2} /$ water nanofluid through conduits with altered cross-sectional shapes, Heat and Mass Transfer 55 (12), 3427-3442 (2019). DOI: 10.1007/s00231-019-02668-0.

28. P.P. Pastushkov, N.V. Pavlenko, A.V. Zherebtsov. Field studies of thermophysical characteristics of heat-insulating materials as part of facade systems, Industrial and civil construction 12, 56-60 (2019).

29. V.A. Maskaikin. Numerical method for studying temperature regimes of an inhomogeneous, structured body, MAI Proceedings 115, 19 (2020). DOI: 10.34759/trd2020-115-19.

30. D.V. Kraynov, R.A. Sadykov. Determination of additional heat fluxes through the elements of a fragment of the enclosing structure, Housing construction 6, 10-12 (2012).

31. V.V. Kozlov. Questions of the accuracy of calculating the reduced resistance to heat transfer and temperature fields, Building and reconstruction 3 (77), 62-74 (2018). 